Retraction

\title{
Retraction: Cadmium Induced Cell Apoptosis, DNA Damage, Decreased DNA Repair Capacity, and Genomic Instability during Malignant Transformation of Human Bronchial Epithelial Cells
}

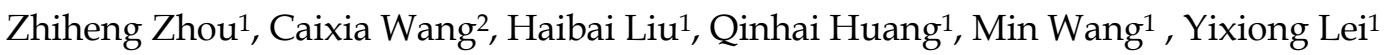

1. School of public health, Guangzhou Medical University, Guangzhou 510182, People's Republic of China

2. Department of internal medicine of Guangzhou First People's Hospital affiliated to Guangzhou Medical University, Guangzhou 510180, People's Republic of China

() Ivyspring International Publisher. This is an open-access article distributed under the terms of the Creative Commons License (http:/ / creativecommons.org/ licenses/by-nc-nd/3.0/). Reproduction is permitted for personal, noncommercial use, provided that the article is in whole, unmodified, and properly cited.

Published: 2014.01.15

Retracted article: Int J Med Sci 2013; I0(II):1485-1496.

This article has been retracted, as it was found after publication that it contains materials taken from other existing publications. The first author Zhiheng Zhou who was responsible for this matter agrees with the retraction and offers apologies to readers and editors of the journal. 